This article was downloaded by: [2007-2008 Nanyang Technological University]

On: 27 April 2009

Access details: Access Details: [subscription number 782527286]

Publisher Routledge

Informa Ltd Registered in England and Wales Registered Number: 1072954 Registered office: Mortimer House, 37-41 Mortimer Street, London W1T 3JH, UK

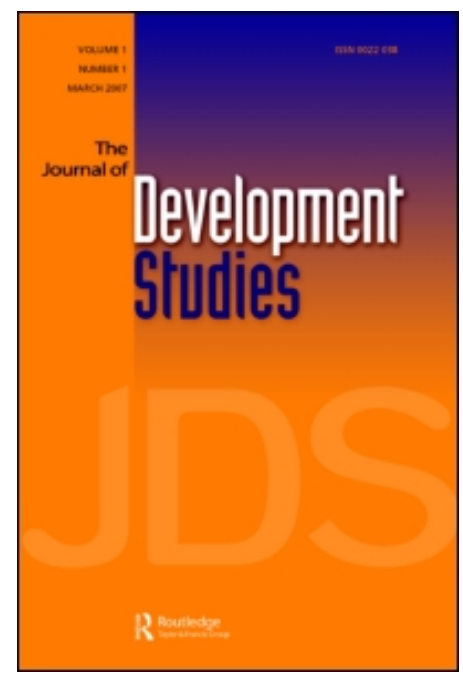

\title{
Journal of Development Studies
}

Publication details, including instructions for authors and subscription information:

http://www.informaworld.com/smpp/title content=t713395137

\section{Globalisation and Developing Countries - a Shrinking Tax Base?}

Joshua Aizenman a; Yothin Jinjarak ${ }^{\text {b }}$

${ }^{a}$ Economics Department, UC Santa Cruz (UCSC), USA ${ }^{b}$ Division of Economics, Nanyang Technological University, Singapore

Online Publication Date: 01 May 2009

To cite this Article Aizenman, Joshua and Jinjarak, Yothin(2009)'Globalisation and Developing Countries - a Shrinking Tax Base?',Journal of Development Studies, $45: 5,653-671$

To link to this Article: DOI: $10.1080 / 00220380802582338$

URL: http://dx.doi.org/10.1080/00220380802582338

\section{PLEASE SCROLL DOWN FOR ARTICLE}

\footnotetext{
Full terms and conditions of use: http://www.informaworld.com/terms-and-conditions-of-access.pdf

This article may be used for research, teaching and private study purposes. Any substantial or systematic reproduction, re-distribution, re-selling, loan or sub-licensing, systematic supply or distribution in any form to anyone is expressly forbidden.

The publisher does not give any warranty express or implied or make any representation that the contents will be complete or accurate or up to date. The accuracy of any instructions, formulae and drug doses should be independently verified with primary sources. The publisher shall not be liable for any loss, actions, claims, proceedings, demand or costs or damages whatsoever or howsoever caused arising directly or indirectly in connection with or arising out of the use of this material.
} 


\title{
Globalisation and Developing Countries - a Shrinking Tax Base?
}

\author{
JOSHUA AIZENMAN* \& YOTHIN JINJARAK** \\ *Economics Department, UC Santa Cruz (UCSC), USA, **Division of Economics, Nanyang \\ Technological University, Singapore
}

Final version received August 2007

\begin{abstract}
This paper evaluates the impact of globalisation on tax bases of countries at varying stages of development. We see globalisation as a process that induces countries to embrace greater trade and financial integration. This in turn should shift their tax revenue from 'easy to collect' taxes (tariffs and seigniorage) towards 'hard to collect' taxes (value added and income taxes). We find that trade and financial openness have a positive association with the 'hard to collect' taxes, and a negative association with the easy to collect taxes.
\end{abstract}

\section{Introduction}

A salient feature of the last 20 years has been the phenomenal increase in trade and financial integration of developing countries alongside declining inflation rates. The greater openness has been reflected both in de facto and de jure measures of trade and financial integration. These trends are consistent with developing countries recognising that, in the era of globalisation, the opportunity costs of inward orientation have increased to a level justifying outward oriented reforms. These reforms include trade liberalisation (reducing tariffs, quotas and other non-tariff trade barriers); financial liberalisation (reducing capital controls and financial repression); and macroeconomic stabilisations (reducing inflation, reducing thereby the financial spread and the cost of borrowing). All of these reforms have a common fiscal denominator - they erode the tax rates from what we call 'easy to collect' taxes. These are the traditional sources of revenue used by developing countries including tariffs, inflation tax and financial repression. ${ }^{1}$ Some of these effects may be compensated by the higher tariff tax base induced by higher imports volume propagated by trade liberalisations. Yet, for countries that start with very high tariff rates, reducing drastically tariff rates, the tax cut effect may dominate the tax base expansion effect. ${ }^{2}$ In these circumstances, globalisation may entail a negative fiscal shock to developing countries, shrinking the tax revenue from traditional taxes.

Correspondence Address: Joshua Aizenman, UC Santa Cruz and the NBER, Economics Department, E2, 1156 High St., Santa Cruz, 95064 USA. Email: jaizen@ucsc.edu 
Short of matching the drop in these taxes by a corresponding cut in fiscal expenditure, affected countries need to increase revenue. To do this, they must rely on alternative 'hard to collect' sources such as Value Added Taxes (VAT), income taxes, sales taxes, etc. These hard to collect taxes, unlike tariffs administered at centralised locations (seaports, airports, etc.) and implicit taxation by means of seigniorage and financial repression, need significant investment in tax collection infrastructure and spending resources on monitoring and enforcement.

The purpose of this paper is to evaluate empirically the impact of globalisation throughout the 1980s-1990s on the vector of taxes collected by countries at varying stages of development. We view the greater trade and financial integration as the outcome of deeper processes often dubbed 'globalisation'. Taking the globalisation process first as exogenous for the purpose of the present investigation, we trace its impact on the tax base, and the ultimate collection of taxes. The factors explaining globalisation include faster, more reliable and cheaper delivery of goods and services across borders, and advances in information technology that allow cheaper fragmentation of production via FDI and outsourcing, and so forth. Specifically, we quantify and explain the degree to which globalisation has contributed to the diminishing fiscal base of developing countries, and the degree to which these countries managed to switch from the traditional easy to collect taxes to new hard to collect taxes. We trace factors explaining the heterogeneity of the negative fiscal shock induced by globalisation and thus explaining the depth of the fiscal adjustment accomplished already by countries at varying levels of development.

Figure 1( $\mathrm{a}$ and $\mathrm{b}$ ) compares trade openness and financial integration between the 1980 s and the 1990s for developing countries segregated into five regions. ${ }^{3}$ The comparison confirms that the globalisation trend is indeed global - openness increased remarkably in all regions. Figure 1 reports the decline in the tariff and inflation rates during that period. On balance, the average tariff and inflation rates declined more in regions where the rates were above the average during the 1980s, indicating convergence of rates to a lower common denominator. Further insight about these developments is gained by comparing the revenue/GDP during the first five years of the 1980s to that during the last five years of the 1990s. Figure 1(e) indicates, as percentages of GDP, a major drop in the revenue from easy to collect taxes (seigniorage + tariff), and a sizeable increase - though at a smaller rate - in the revenue from hard to collect taxes (VAT + income). While the drop in easy to collect effective tax rates is more pronounced for high income countries, the greater initial base of hard to collect taxes in these countries relative to developing countries implies a net increase in total taxes of 6 per cent in the first group, and a drop of 2 per cent in the second. The position of four South Asian countries ${ }^{4}$ is in between the high income and the developing countries: the large increase in the revenue from hard to collect taxes more than offsets the drop in the revenue from the easy to collect taxes, increasing total tax revenue by 4 per cent. These figures mask significant heterogeneity of the adjustment across countries, an issue that will be investigated in this paper using regression analyses.

Before turning to the empirical work, we note the sizeable theoretical literature and growing empirical research on tax effort, tax evasion and avoidance, and administration (see Slemrod and Yitzhaki (2002) and Slemrod (2007) for a comprehensive survey and discussion). Applying cost-benefit analysis, models 
(a)

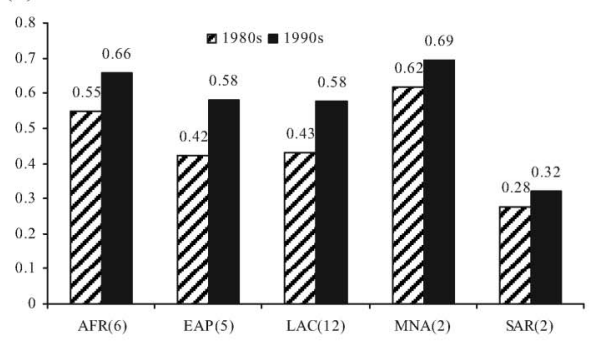

(c)

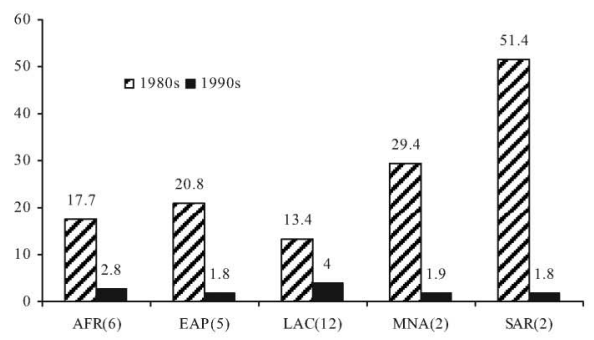

(b)

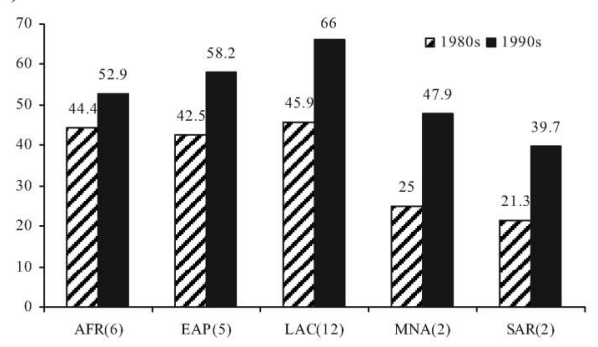

(d)

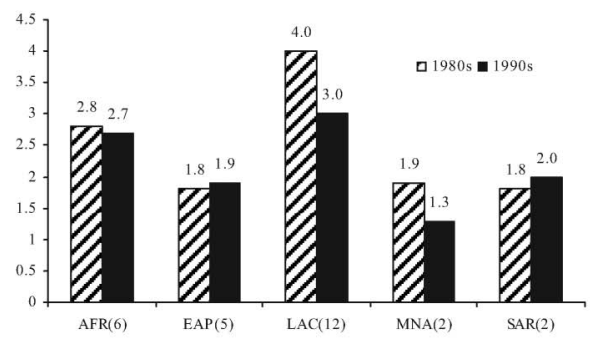

(e)

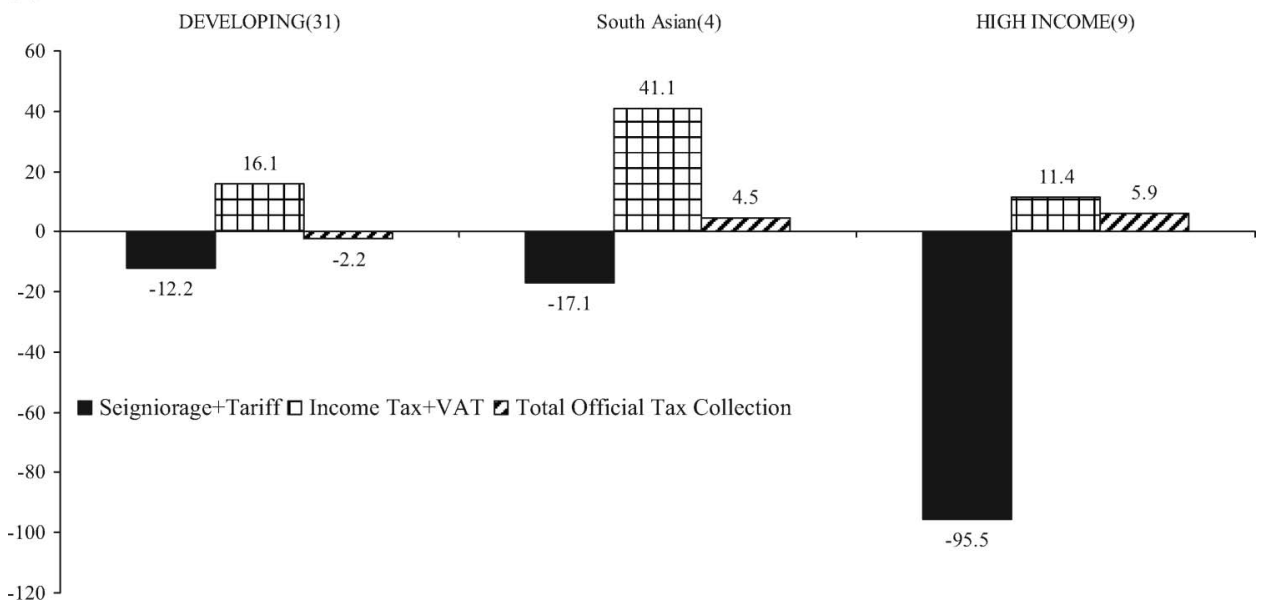

Figure 1. (a) (Exports + Imports)/GDP. The actual trade share ranges from 0 to 1; (b) Index of capital mobility. The index ranges from 0 to 100; (c) Tariff rates. Weighted average rates; (d) Inflation Logarithms of the CPI inflation rates; (e) Tax/GDP adjustment (\%) from 1980-1984 to $1995-1999$.

inspired by Allingham and Sandmo (1972) explained the interplay between tax underpayment and the tax authority's effort to identify and limit tax frauds. This occurs in circumstances where agents gamble by underpaying taxes, and where the probability of detection and the resultant penalties are determined by the resources committed by the regulator, and the efficacy of institutions. These models identify 
several factors explaining tax underpayment, including the tax burden, the stringiness and efficacy of enforcement, the penalties associated with tax underpayment and the degree of risk aversion. Using Chilean tax revenues to estimate the impact of changes in enforcement spending, Engel et al. (2001) found that US\$1 of additional enforcement spending increases VAT revenues by US\$31, and a 10 per cent increase in spending could reduce evasion from its current rate of 23 to 20 per cent. Reliable evasion estimates are difficult to obtain because of the limited availability of data. The empirical assessments of tax effort and avoidance frequently rely on macro estimates of the 'black economy', quantifying the revenue lost due to underpayment of taxes. ${ }^{5}$ Some studies moved beyond inferring tax underpayment by means of macro methods, using information from tax audits evaluating compliance. Not surprisingly, the estimates of VAT non-compliance vary across countries, from about 2.5 per cent in the Netherlands to over 34 per cent in Italy on average during 1994-1996 (Nam et al., 2003). While informative, the above methods provide us with little guidance for dealing with the impact of a common macro shock, like globalisation, on the tax revenue in a panel of countries. Our approach is to implement an extended version of the methodology used by Cukierman et al. (1992) for the assessment of international use of inflation tax, adding controls associated with the impact of globalisation on easy to collect taxes.

We outline the conceptual framework in the following section. Data and descriptive statistics are presented in Section III. Section IV reports the benchmark panel regressions. We provide robustness checks together with quantification of the economic significance in Section V. Section VI closes the paper with concluding remarks.

\section{Conceptual Framework}

Our empirical specification controls for variables suggested by a model outlined in the earlier version of our paper (see Appendix A of Aizenman and Jinjarak, 2006). Our benchmark model is adopted from Cukierman et al. (1992), explaining the obstacles to tax reforms in polarised countries, characterised by political instability. They focused on the case where fiscal revenue can be raised by taxes associated with collection costs (income taxes), and implicit taxes where the collection cost is zero (inflation tax). They assumed implementation lags - the present policy maker determines the efficiency of the tax system next period. This implies strategic choice of the tax system's efficiency - the current policy maker may choose an inefficient future tax system in order to constrain the fiscal revenue available to future policy makers. This prevents future policy makers from spending in ways that are viewed as inferior from the vantage point of the present policy maker. We add endogenous tax evasion, and model the optimal enforcement of the hard to collect taxes. Following Cukierman et al. (1992), the model suggests the following types of controls:

1. Macro variables dealing with the tax base and with the level of economic development.

2. Controls dealing with the sectoral composition of the economy, reflecting differential costs of tax evasion and collection across economic activities.

3. Variables dealing with political instability, polarisation and quality of institutions, reflecting the model's prediction that the present tax infrastructure 
reflects past public investment, which in turn is affected by the incentives facing the previous administrations.

Specifically, the variables we use are:

1. Globalisation factors: our conjecture is that, if globalisation reduces the fiscal revenue from traditional taxes, it would set in motion forces that will increase the collection from alternative, less traditional taxes, including the VAT. Consequently, we expect the globalisation factors, measured by Trade Openness and Financial Openness, to increase VAT collection and reduce seigniorage and tariff revenue (the last result would hold if the adverse revenue effect of lower tariffs dominates the increase in tariff revenue due to the growth of imports, a conjecture that is verified as part of the empirical study). ${ }^{6}$ Slemrod (2004) found that up to the early 1990s measures of openness were negatively associated with statutory corporate tax rates, although not with revenues collected as a fraction of GDP. One problem with using statutory rates in the developing countries context has to do with tax incentives. At any rate, our study is closely related to that of Slemrod (2004), but we emphasise effective tax collection.

2. Agriculture share: easy to collect taxes should be applied more heavily in a country with larger agricultural share in GDP, where the collection of income and VAT is challenged by the widespread distribution of production among geographically diffused farmers. Another possibility is that in countries where the manufacturing sector is relatively small, it is optimal for firms either to have small size to evade official detection and taxes, or to have a very large size to overwhelm the system and extract more than proportionate benefits. ${ }^{7}$

3. Urbanisation: we expect that it is more difficult to administer and collect hard to collect taxes in less urbanised and more rural countries. However, it is also possible that urbanisation is associated with a larger underground economy, inducing the use of seigniorage to tax such an informal sector. Equally important in industrial countries is the issue of income shifting through incorporation by high-income individuals, though it is still an open question to what degree this practice applies to developing countries.

4. Institutional quality and political durability: we expect that countries with better institutional quality and more stable politics tend to invest more in the tax collection infrastructure, collecting more from hard to collect taxes and less from easy to collect taxes. ${ }^{8}$

Suppressing for simplicity the time and cross-section subscripts, the estimation equation is given by Equation 1 with the expected sign of coefficients indicated below the regressors;

(1)

\begin{tabular}{|c|c|c|c|c|c|c|c|}
\hline $\begin{array}{l}\text { Tax } \\
\text { revenue }\end{array}$ & $=\mathrm{f}[$ & $\begin{array}{c}\text { Trade } \\
\text { Openness, }\end{array}$ & $\begin{array}{l}\text { Financial } \\
\text { Openness, }\end{array}$ & $\begin{array}{c}\text { Institutional } \\
\text { Quality, }\end{array}$ & $\begin{array}{c}\text { Political } \\
\text { Durability, }\end{array}$ & Urbanisation, & $\begin{array}{c}\text { Agriculture ] } \\
\text { Share }\end{array}$ \\
\hline $\begin{array}{l}\text { Ird to } \\
\text { llect }\end{array}$ & & + & + & + & + & + & - \\
\hline sy to & & - & - & - & - & - & + \\
\hline
\end{tabular}




\section{Data and Descriptive Statistics}

Our sample spans from 1980 to 1999 over 60 countries. The Data Appendix provides sources and details of the sample. A third of these countries have observations across the 1980s and the 1990s sufficient for panel regressions. Figure 2(a) reports total tax/ GDP in the early 1980s (measured horizontally) and in the late 1990s (measured vertically). The further away is a country from the 45-degree ray, the greater is the change over time in that country. Figure 2(b and c) reports the GDP share of revenue colleted by easy to collect taxes and by hard to collect taxes. For most developing countries, the share of easy to collect declined, whereas the share of hard to collect taxes increased. The average total tax revenue/GDP declined from 0.182 to 0.176 . The average revenue/GDP of easy to collect taxes declined during the period from 0.060 to 0.046 (see Figure 2(b)); whereas average tax revenue/GDP of hard to collect taxes increased slightly from 0.086 to 0.093 (see Figure 2(c)). Interestingly, the overall cross-country patterns are non-linear, characterised by an inverted U-shape curve (see the quadratic regression lines in Figure 2(b) and 2(c)). In both figures, the left arch of the fitted $U$ curve is close to the 45-degree ray for countries below the sample mean, with increasing divergence from the 45-degree ray for countries above the sample mean. The concavity of the cross-country patterns is more pronounced in Figure 2(b) suggesting that countries that had previously relied heavily on the easy to collect taxes confronted greater losses. Figure 2(c) suggests that countries below the mean of revenue from hard to collect taxes in the early 1980s ended up increasing the revenue in the late 1990s. Both figures are consistent with the notion that globalisation entails fiscal convergence. Figure 2(d) compares the total government expenditure/GDP between the early 1980s and the late 1990s and shows that the average drops from 0.264 to 0.234 .

To gain perspectives about the net adjustment, Figure 3(a) reports tax revenues as percentages of GDP in the early 1980s across income groups. Most of the variation across the four income groups was in the revenue from hard to collect taxes, which was about 8 per cent of GDP for the low income, progressing upward and reaching 17 per cent of GDP in the high income countries. In contrast, there was little variation in the revenue from easy to collect taxes across the income groups: it was 6 per cent of GDP for the low income and 5 per cent of GDP for the high income countries. The total official tax collection to GDP in these four income groups mimics the patterns of the hard to collect taxes: it was about 16 per cent of GDP for the low income group, progressing upward with GDP per capita and reaching 28 per cent of GDP for the high income group. Figure 3(b) reports the changes in total taxes/GDP, and in easy to collect and hard to collect taxes/GDP between the early 1980 s and the late 1990s across the four income groups. Overall, the record is mixed. The drop in the revenue from easy to collect taxes was larger for the higher income groups (in fact the revenue from easy to collect taxes went up for the middle income group by $8.4 \%$ ). Both the high income and the middle income groups managed to increase the revenue from the hard to collect taxes significantly $(11 \%$ and $40 \%$, respectively) and increased the total tax/GDP by 6 per cent and 10 per cent, respectively. The increase in revenue from the hard to collect taxes was rather timid for the upper and the low income countries (13\% and $12 \%$, respectively), less than what was needed to compensate for the drop in revenue from easy to collect taxes. 

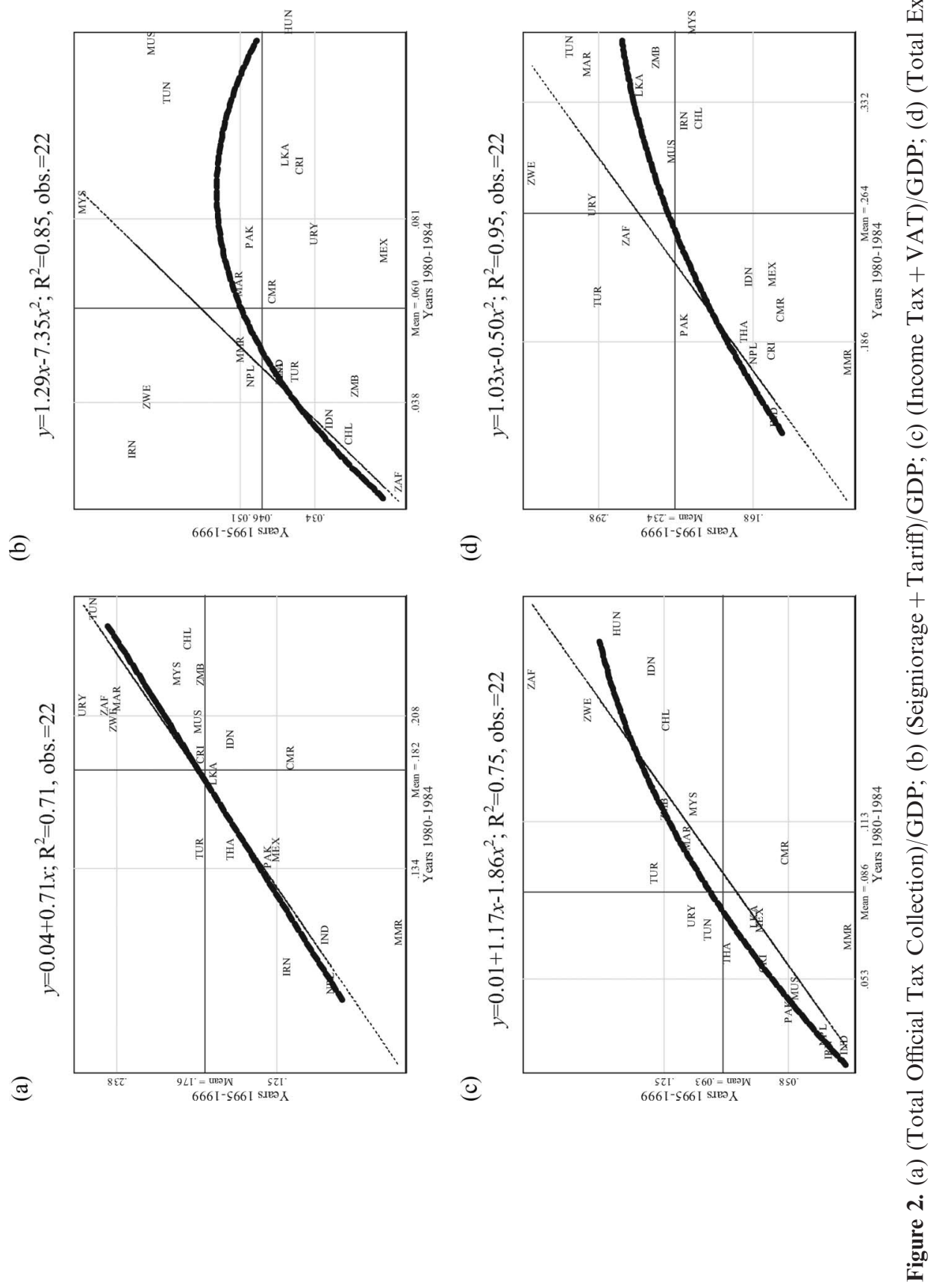


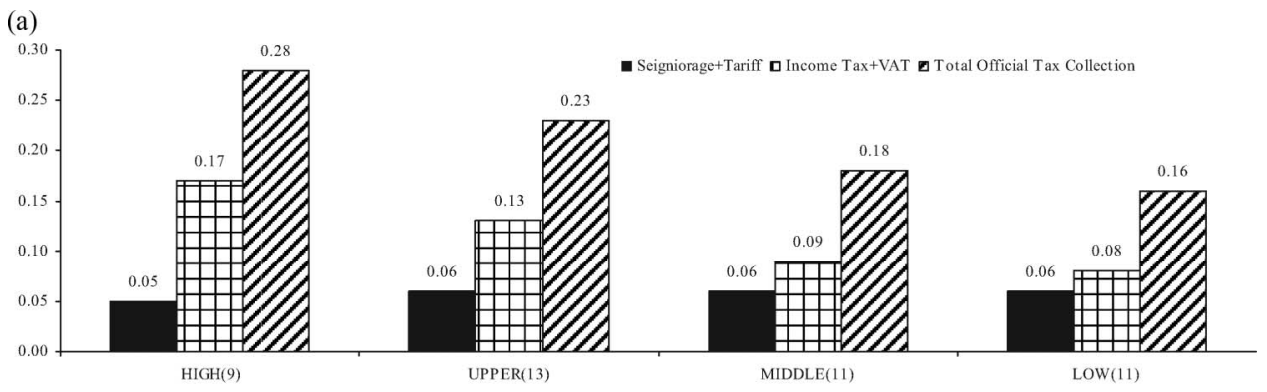

(b)

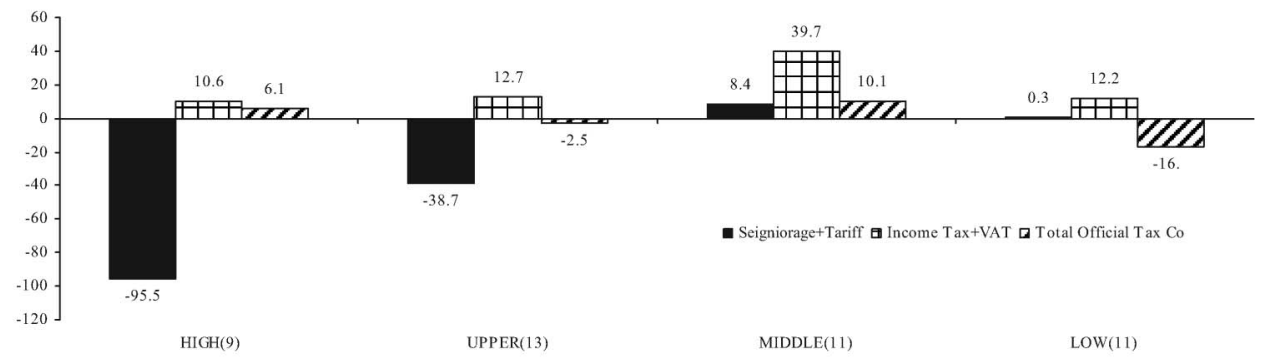

(c)

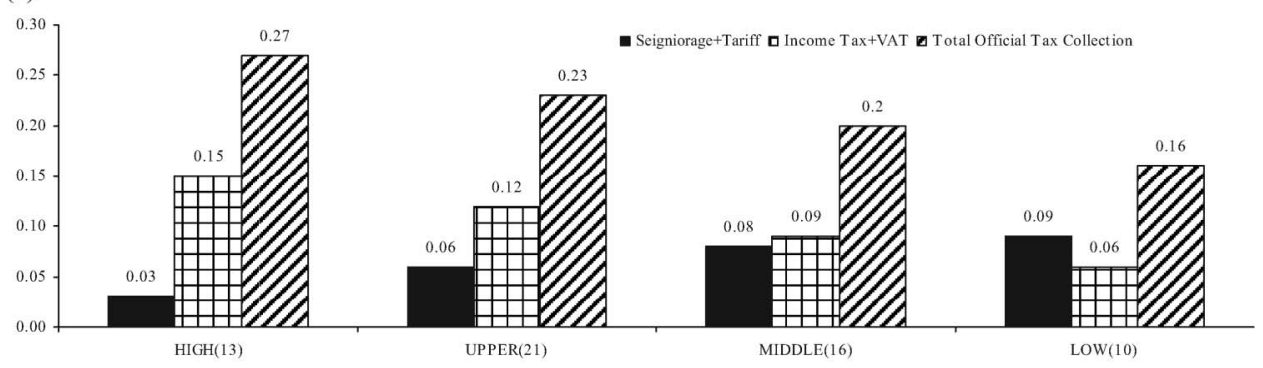

(d)

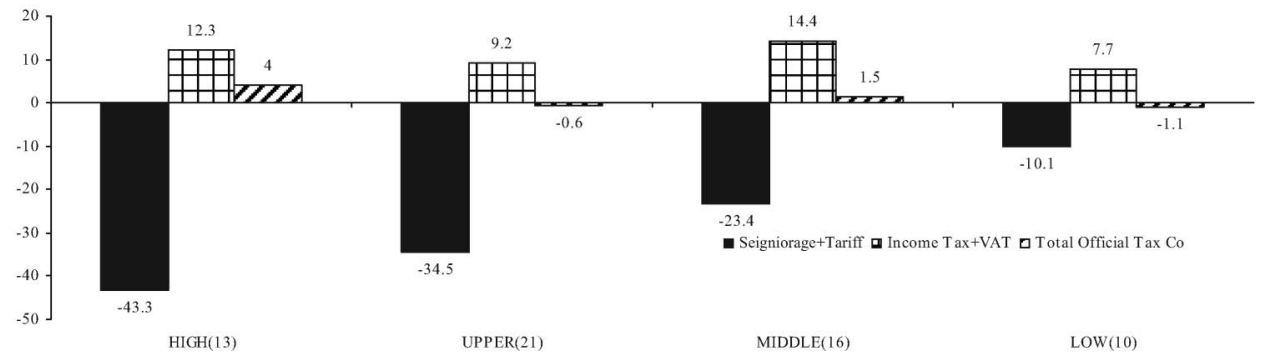

Figure 3. (a) Tax/GDP, 1980-1984; (b) Adjustment of tax/GDP, \% change of 1995-1999 from 1980-84; (c) Tax/GDP, 1990-1994; (d) Adjustment of tax/GDP, \% change of 1995-1999 from 1990-1994.

This induced a drop in total tax revenue of 3 per cent for the upper income countries and 17 per cent for the low income developing countries. Seemingly, countries exhibit complex non-linear patterns of adjustment, where the middle-income 
developing countries adjust more easily than the upper- and the lower-income developing countries.

Figure 3(c and d) summarises the changes in tax revenues in the 1990s. Figure 3(c) reports the patterns of tax revenues in the early 1990s, and Figure 3(d) traces the tax revenue changes between 1990-1994 and 1995-1999. The middle-income countries experienced a sizeable contraction in the easy to collect tax revenue (by about $35 \%$ ), reducing the overall tax revenue by about 1 per cent. The low-income countries experienced a similar drop in total tax revenue, accounted for by a smaller drop in the easy to collect tax revenue (by about $10 \%$ ).

Globalisation, being a common shock, may induce fiscal convergence across countries. Figure 4 confirms this conjecture. It shows a gradual decline in the coefficient of variation of tax revenues/GDP during the 1980s-1990s. This effect differs across taxes: the coefficients of variation of seigniorage and tariff revenue/ GDP during the 1980s-1990s declined by about 40 per cent, as opposed to only about 4 per cent for the hard to collect taxes. At any rate, the reductions in the coefficients from 1980-1984 to 1995-1999 are statistically significant at the 1 per cent level. Apparently, improving the performance of the hard to collect taxes seems more challenging than reducing the use of easy to collect sources of revenue. ${ }^{9}$

\section{Benchmark Panel Estimation}

For our regression analysis, an important issue is how to measure globalisation factors. While we take the globalisation process, measured by trade and financial openness, as exogenous factors inducing fiscal adjustment in the next period, we use instrumental methods to control for endogeneity of trade openness to geographic and structural factors advanced in the gravity equation literature. ${ }^{10}$ Elsewhere, applying instrumental variables for trade openness has been used by Frankel and Romer (1999) to study the impact of trade openness on income per capita, Hall and Jones (1999) to study the impact of social infrastructure on income per capita, and Persson and Tabellini (2003) to study the impact of political institutions on

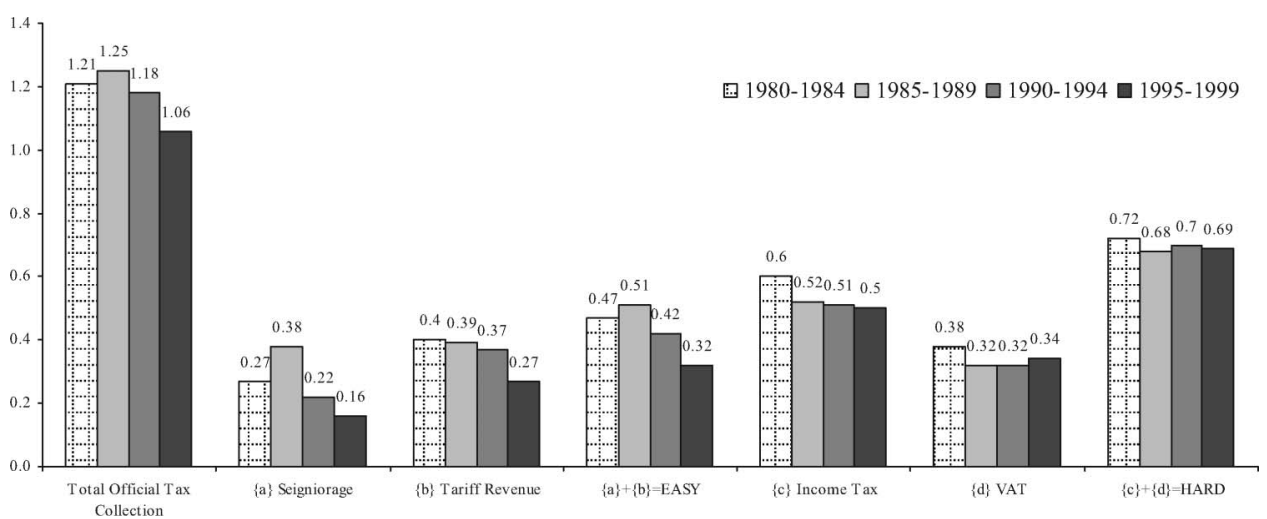

Figure 4. Fiscal convergence. Coefficients of variation, measured over non-overlapping fiveyear periods from 1980-1999. 
productivity and growth. Following Frankel and Romer (1999), we use the gravity instrument for trade openness, which is constructed from geographical determinants of bilateral trade, including log of distance, $\log$ of partner country population, log of land area, dummy variables for common language, common land border and landlocked status. After estimating the gravity model, we aggregate the exponent of the fitted values across bilateral trading partners to arrive at an estimate of total trade share for a given country, dubbing it as the 'gravity trade share'. Our gravity trade share estimation explains around 35 per cent of variation in the actual trade shares from 1975 to 1999 . The correlation between the actual and gravity trade shares is 44 per cent across countries. There is also an increasing trend of the gravity trade share across countries over the sample period. ${ }^{11}$ In what follows throughout, we shall use this gravity trade share as a measure of trade openness to estimate its impact on tax base adjustments. Definition of other variables in the regressions can be found in the Data Appendix.

Table 1 reports the benchmark panel regressions. For each of the tax equations, we use fixed effects estimation controlling for first-order autoregressive disturbances. We take into account reverse causality from fiscal adjustment by lagging by one year the globalisation factors and explanatory variables in the regression analysis. Because our estimation is quite demanding of data, only 20 of 60 countries have sufficient data. ${ }^{12}$ At any rate, the benchmark panel estimation yields encouraging results. We find that trade and financial openness have a positive relationship with hard to collect taxes, and a negative relationship with the easy to collect taxes. As a group, hard to collect tax revenue responds positively to trade and financial openness. VAT and Income Taxes are also associated with the globalisation factors with the expected positive sign. Though the coefficient of Trade Openness on Income Taxes and the coefficient of Financial Openness on VAT are found to be insignificant, these findings are not entirely surprising given the ongoing debates on how to effectively tax corporations and financial services.

Of the easy to collect taxes expected to be hard hit by globalisation factors, only Seigniorage is found to respond significantly in statistical term to Trade Openness. Except for the coefficient of Financial Openness on Tariffs, the components of easy to collect taxes respond to globalisation with a correct negative sign. A negative association between Trade Openness and Tariffs is consistent with previous studies on trade liberalisation and tariff revenue (see, for example, Baunsgaard and Keen (2005)). Financial Openness is negatively associated with Seigniorage but positively with Tariffs; the latter, though insignificant, may be justified by a possibility that openness and development of the financial system help to improve trade misinvoicing problems. As a group, easy to collect tax revenue responds strongly negatively to Trade Openness, but insignificantly positive to Financial Openness.

Turning to other control variables, we find that better Institutional Quality is associated with a lower use of easy to collect taxes. VAT and Tariffs respond negatively to Political Durability. Although the negative relationships of VAT with Political Durability and Institutional Quality seem counterintuitive, it is not impossible given the difficulty in implementing and adjusting VAT collection for industrial countries facing even more organised and sophisticated tax frauds. ${ }^{13}$ As expected, Urbanisation increases VAT collection, but we do not find supportive evidence that Urbanisation facilitates the use of Seigniorage to tax the informal 


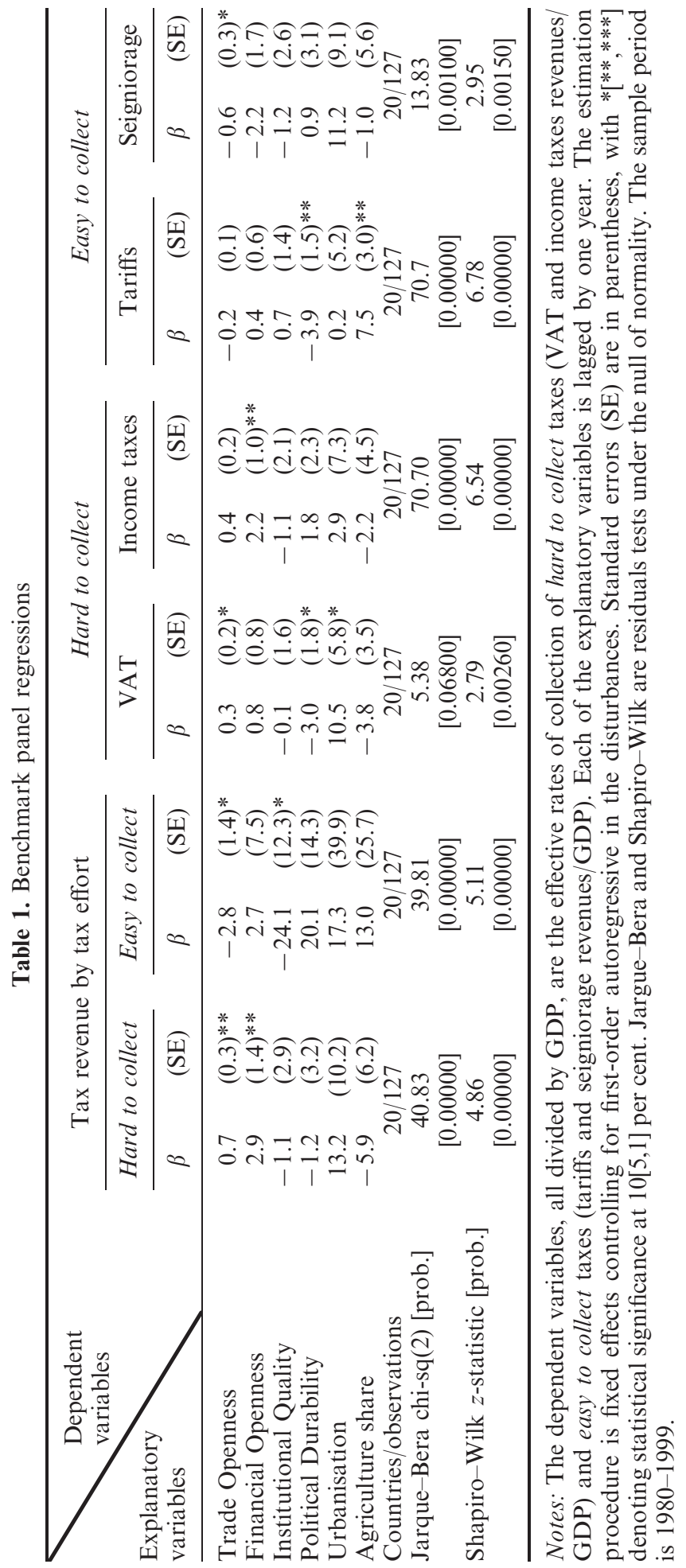


sector. Tariff revenue is found to be increasing with the Agriculture Share in GDP, in line with the theoretical prediction.

Overall the benchmark regressions are supporting our conjecture that above and beyond institutional, political and structural factors, the globalisation forces influence the size and composition of the tax base and tax revenue. One issue with this set of estimations is that we have only 20 countries each with six or seven years of observations. The Jarque-Bera and Shapiro-Wilk residuals tests reject the null of normality in all except for residuals from the VAT equation. With such limited data availability, our hopes lie in the more robust estimation technique in the following section.

\section{Robustness and Economic Significance}

One way to improve upon the benchmark regressions is to take into account a joint determination among easy to collect and hard to collect taxes, and that different taxes have different evasion characteristics, so that the optimal tax mix and its transitions emerge naturally. Zellner's (1962) Seemingly Unrelated Regression (SUR) is appropriate in this context because it captures the efficiency due to the correlation of the disturbances across equations. Since we do not model tax equations as having a structural relationship in the sense that one type of tax appears as an explanatory variable for the others, each revenue equation is, by itself, a classical regression, and therefore the parameters could be estimated consistently, if not efficiently, by the Ordinary Least Squares (OLS) (Ruud, 2000) as we do in the previous section. In a cross-section context, the OLS and generalised least squares (GLS) on the whole system are identical when the equations have identical explanatory variables (Greene, 2002). In a panel data framework, Baltagi (2005) shows that a blockdiagonal covariance matrix between the disturbances of different equations makes GLS on the whole system equivalent to GLS on each equation separately, but not when the same explanatory variables appear in each equation. To directly apply SUR with a set of our benchmark regressions of the previous section, we use the same explanatory variables. In order to gain estimation efficiency from SUR, we develop a two-step approach. In the first step, we generate a new set of interaction variables between globalisation factors and other control variables based on their statistical significance in the benchmark regressions of Table 1. In the second step, we apply SUR to the set of benchmark regressions adding the interaction variables, the inclusion of which varies across regressions. Not only does this two-step procedure allow us to capture estimation efficiency from SUR, but we also get a further insight from interacting globalisation factors with institutional, political, and structural variables. Essentially, we can then understand, for example, whether economic integration affects countries with a high level of institutions differently to countries with a low level.

Table 2 reports SUR estimates with interactions. Besides the control variables outlined above, we also include a one-year lag of the dependent variable to improve the fit and control for possible dynamics of tax collection. Coefficients of the main explanatory variables are similar to those found in the benchmark regressions. The coefficient of Political Durability on Income Taxes and the coefficient of Urbanisation on Seigniorage are now statistically significant. The latter thus 


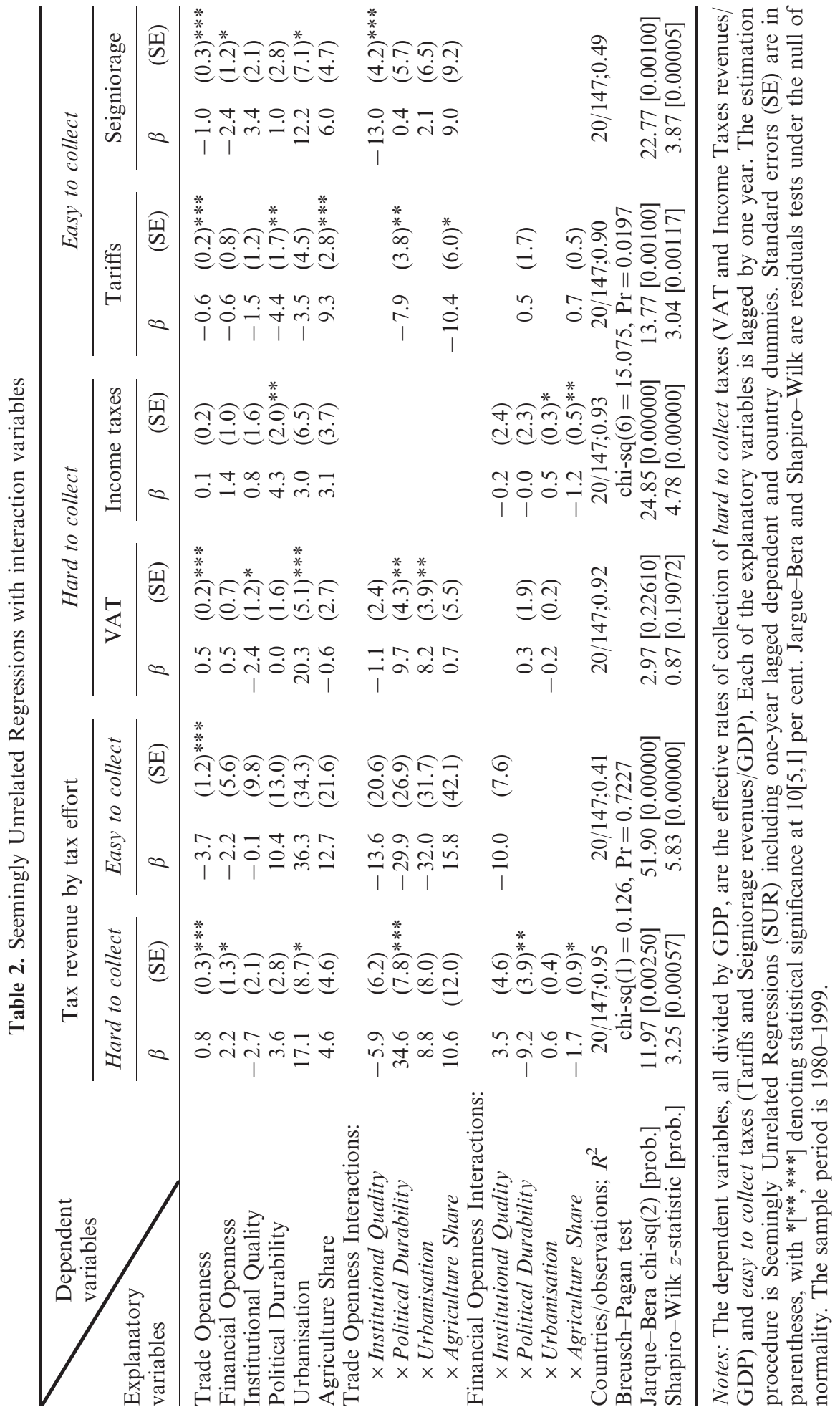


supports the conjecture that urbanisation is associated with an underground economy, inducing the use of seigniorage to tax this informal sector. SUR with interaction variables explains around 40-90 per cent of variation in the data. We also find that the normality of residuals cannot be rejected for the VAT equation based on the Jarque-Bera and Shapiro-Wilk tests, and that the variance of the residuals are independent of the explanatory variables for the hard to collect and easy to collect SUR regressions based on the Breusch-Pagan test. Although the improvement of these SUR estimates upon the benchmark estimation is rather small across the board in term of residuals normality, we believe that the inclusion of control variables suggested in the literature is comprehensive and thus a future expansion of countryyear observations beyond the current sample will help increase the overall efficiency of the estimation.

Fortunately we gain several further insights from the interaction variables. Seigniorage responds more negatively to higher Trade Openness and Institutional Quality. That is, countries with low level of Institutional Quality have found the fiscal adjustment more challenging, frequently ending with diminishing tax revenue. When Political Durability is longer, Trade Openness has a larger positive impact on VAT and hard to collect tax revenues, and a larger negative impact on Tariffs. Furthermore VAT also responds favourably to Trade Openness when countries have a high level of Urbanisation. Countries with a higher Agriculture Share in GDP scale down Tariff revenue in response to Trade Openness, and Income Taxes in response to greater Financial Openness. Income taxes of countries with a higher level of urbanisation tend to respond positively to Financial Openness. We are intrigued to find that hard to collect tax revenue tends to fall when Political Durability and Financial Openness are both at a high level. The rapid financial liberalisations of the 1990s seem to pose a greater fiscal challenge on a relatively durable government.

We conclude our empirical analysis by quantifying the economic significance of the globalisation factors. Table 3 summarises the impact of a one standard deviation change of the globalisation factors on taxes/GDP. The calculation is based on the SUR estimates reported in Table $2 .{ }^{14}$ Summing up its individual and interaction effects, Trade Openness increases hard to collect tax revenue by 4.5 per cent, of which two-thirds of the impact comes from interactions with Political Durability. The individual effect of Trade Openness is responsible for a reduction of 8 per cent in easy to collect tax revenue. In response to Trade Openness, VAT increases 3.1 per cent, Tariffs and Seigniorage drop by 2.4 per cent and 4.1 per cent, respectively. About twothirds of the impact on VAT is a result of the interactions, further highlighting the role of administration costs in collection. Financial Openness has a small negative effect on hard to collect tax revenue, mainly from interactions with Political Durability and Agriculture Share, partially an intriguing result discussed earlier. In total, the globalisation factors increase, as percentages of GDP, hard to collect revenue by 3 per cent and decrease easy to collect revenue by 8 per cent. Following a one standard deviation increase of globalisation factors, VAT increases by 3.1 per cent, Income Taxes increase by 0.7 per cent, Tariffs drop by 2.4 per cent, and Seigniorage drops by 4.6 per cent. Taken together with our earlier discussion on the overall tax revenue adjustment, these numbers imply that the globalisation factors are responsible for about a fifth of the 16 per cent increase of hard to collect base/GDP and two-thirds of the 12 per cent drop of easy to collect base/GDP in developing countries. 


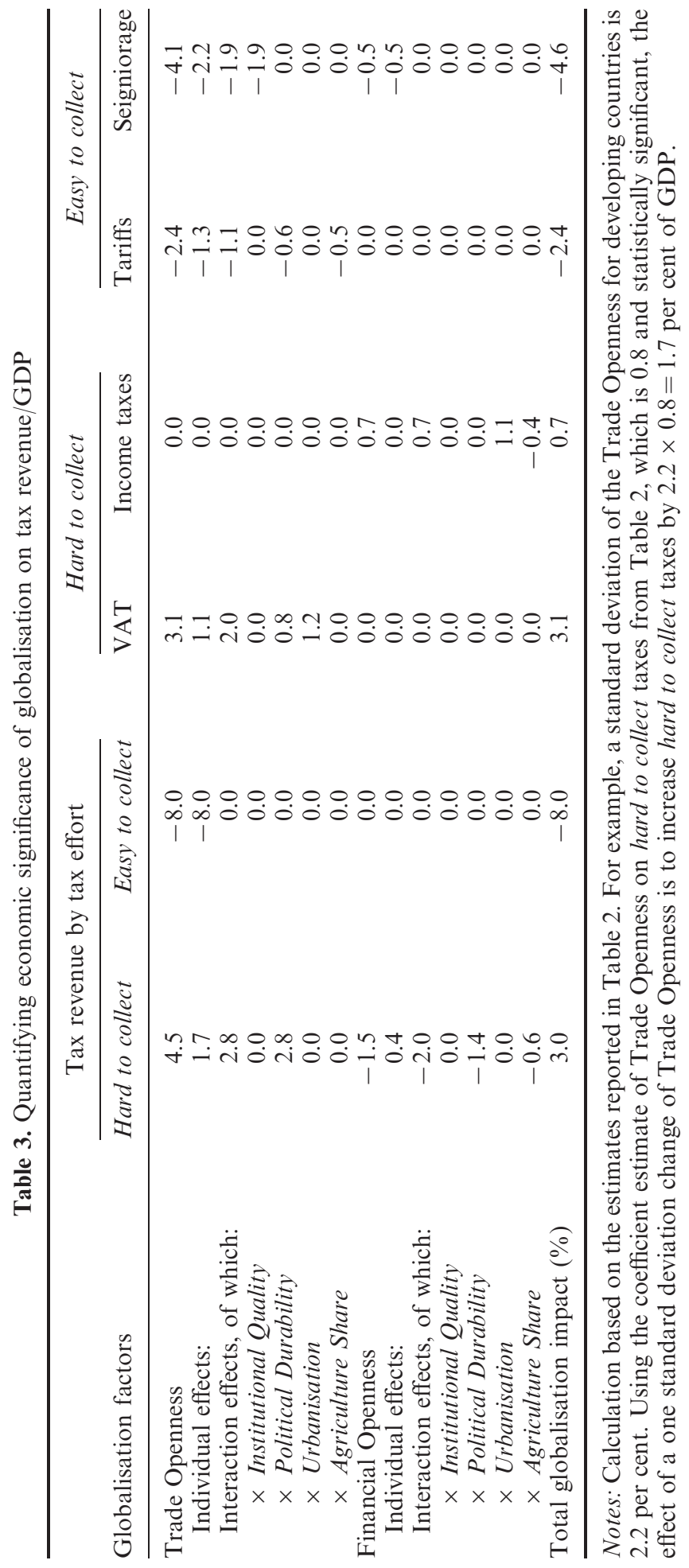




\section{Concluding Remarks}

Our study found that globalisation has imposed new fiscal challenges on developing countries, forcing them to scale down traditional easy to collect revenue sources. A good share of developing countries managed the adjustment by shifting the tax revenue to the hard to collect taxes. Yet, countries with a low level of institutional quality have found the adjustment more challenging, frequently ending with a drop in the net tax revenue/GDP. Trade and financial openness exert an economically significant impact on tax revenue/GDP over the period of our investigation. A fifth of the increase in hard to collect taxes/GDP and two-thirds of the drop in easy to collect taxes/GDP can be traced back to the individual and interaction effects of globalisation factors.

This paper is another step in understanding the evolution of tax revenue, tax base and tax effort across countries. Among fiscal issues in the global context, we have yet to touch on the consequences of competition over tax revenue among fiscal institutions. Our study has also focused only on half of the adjustment, as we do not include government expenditure as a potential determinant of tax policy. It is possible that part of the adjustment of hard to collect and easy to collect tax to globalisation is accomplished by opening a larger fiscal gap, or by scaling down government spending. ${ }^{15}$ At this point, we do not have sufficient data to allow us to do more rigorous analysis beyond a simple period comparison reported in Figure 2(d). Another possible empirical extension is to directly quantify tax effort across countries. We should also note that the presence of an informal economy may overstate the effective tax rates used throughout the paper. The association between tax revenue and the informal sector in developing countries warrants further investigation.

\section{Acknowledgements}

We would like to thank Swisa Ariyapruchya and Jake Kendall for excellent research assistance, and Tuan Minh Le and the participants at the Public Finance World Bank Workshop for useful comments. Joshua Aizenman gratefully acknowledges the support of a COR grant, UCSC. Useful comments by two anonymous referees and the editor are gratefully acknowledged. Any errors are ours. The views expressed herein are those of the authors and do not necessarily reflect the views of the NBER.

\section{Notes}

1. Developing countries' reliance on easy to collect taxes has been explained by their limited institutional capacities, political instability, and polarisation. Studies explaining the reliance on easy to collect taxes in developing countries include Phelps (1973), Vegh (1989), Cukierman et al. (1992), Giovannini and De-Melo (1993), Aizenman and Guidotti (1994), Emran and Stiglitz (2005), and Gordon and Li (2007). The impact of globalisation on the pattern of taxation in the OECD countries has been the focus of Rodrik (1998); see also Tanzi and Zee (2000) and Ebrill et al. (2002). Space considerations limit our coverage of the large background literature dealing with public finance in developing countries. See Aizenman and Jinjarak (2006), Slemrod and Yitzhaki (2002) and Slemrod (2007) for a comprehensive survey and discussion.

2. This would be the case in countries where, due to political economy considerations, the initial tariff rate was set in order to maximise the tariff revenue. One purpose of our analysis is to quantify the ultimate revenue impact of tariff cuts, allowing us to test which of the two effects dominate. Similarly, 
macroeconomic stabilisation may increase economic growth, with ambiguous effects on seigniorage. Yet, if most countries operate on the 'proper' part of Laffer's tax curve, one expects that globalisation would reduce the tariff and the seigniorage revenue/GDP ratios.

3. Low*, middle**, and upper income*** developing countries classification is based on income and regional classification of the World Bank (http://www.worldbank.org/data/countryclass). Developing countries are: Africa: Cameroon*, Gabon***, Guinea*, Lesotho*, Mauritius***, Namibia**, South Africa***, Zambia*, Zimbabwe*; East Asia: Indonesia**, Korea***, Malaysia***, Myanmar*, Thailand**; Eastern Europe: Azerbaijan**, Belarus**, Bulgaria**, Croatia***, Czech Republic***, Estonia***, Hungary***, Latvia***, Lithuania***, Poland***, Romania**, Russian Federation***, Turkey***; Latin America: Argentina***, Bolivia**, Brazil**, Chile***, Colombia**, Costa Rica***, Mexico***, Nicaragua*, Paraguay**, Peru**, Trinidad and Tobago***, Uruguay***, Venezuela***; Middle East and North Africa: Iran**, Morocco**, Tunisia**, South Asia: India*, Nepal*, Pakistan*, Sri Lanka**. High-income countries are: Australia, Canada, Cyprus, Denmark, Iceland, Israel, Japan, Malta, Norway, Slovenia, Sweden, Switzerland, United Kingdom.

4. India, Nepal, Pakistan and Sri Lanka.

5. A review of these methods can be found in Schneider (2004) and Alm et al. (2006).

6. See Fisman and Wei (2004) and Aizenman (2004) for fiscal implications of trade mis-invoicing.

7. Though interesting, there are no formal tests on the relationship between firm size distribution and tax evasion across countries.

8. Admittedly, Institutional Quality covers a wide range of aspects.

9. We should also note that there is another, hard to measure but easy to collect tax - government revenue from financial repression. Government can impose controls on international capital flows and domestic financial intermediaries as a form of taxation. The resultant wedge between effective external and domestic interest rates of public debt is the financial repression tax, which is essentially a subsidy on interest payments on government liabilities. As discussed in Giovannini and De-Melo (1993), there are also potential complementarities between financial repression revenue and seigniorage because (i) inflation implies low real interest rates facing savers, and thus interest savings on government liabilities, and (ii) negative real interest rates on savings increase money demand, that is, the inflation tax base. Financial repression revenue is calculated by multiplying the stock of outstanding domestic debt by the financial repression tax rate, which is the interest rate differential in local currency between the effective external and domestic interest rates. Financial repression revenue may be negative (i.e. the effective foreign interest rate is smaller than the effective domestic interest rate), reflecting a lower cost of foreign borrowing relative to domestic borrowing facing a government. We focus on seigniorage because there is a high positive correlation between seigniorage and government revenue from financial repression (about 0.50). Limited data availability on a panel of tax revenue from financial repression prevents us from adding this implicit tax to the figures dealing with easy to collect taxes. Hence, these figures tend to understate the shrinking of easy to collect taxes in our sample.

10. See for example Anderson and van Wincoop (2003) and Helpman et al. (2007).

11. A simple fixed effect regression of gravity trade share on time trend shows a statistically significant increase of 0.3 per cent per year from 1980 to 1999.

12. Argentina, Cameroon, Chile, Colombia, Costa Rica, Hungary, India, Indonesia, Mexico, Morocco, Pakistan, South Africa, Thailand, Trinidad and Tobago, Tunisia, Turkey, Uruguay, Venezuela, Zambia and Zimbabwe.

13. The pan-European VAT system and tax base harmonisation debated in the European communities is a good example. See for example Financial Times (2006) and Financial Times (2007).

14. For example, a standard deviation of the Trade Openness for developing countries is 2.2 per cent. Using the coefficient estimate of Trade Openness on hard to collect taxes from Table 2, which is 0.8 and statistically significant, the effect of a one standard deviation change of Trade Openness is to increase hard to collect taxes by $2.2 \times 0.8=1.7$ per cent of GDP.

15. See Rodrik (1998) for some discussion on globalisation and the size of government expenditures. In addition, the ramification of fiscal adjustment on macro economy in general is less well understood in the case of developing countries. Talvi and Vegh (2005) study the association between tax base volatility and macroeconomic policies in developing countries. For OECD, Alesina et al. (2002) found that various types of taxes also have negative effects on profits but interestingly, the effects of government spending on investment are larger than those of taxes. 


\section{References}

Aizenman, J. (2004) Financial opening and development: evidence and policy controversies. American Economic Review, 94(2), pp. 65-70.

Aizenman, J. and Guidotti, P.E. (1994) Capital controls, collection costs, and domestic public debt. Journal of International Money and Finance, 13(1), pp. 41-54.

Aizenman, J. and Jinjarak, Y. (2006) Globalization and developing countries - a shrinking tax base? NBER Working Papers No. 11933 (Cambridge, MA: NBER).

Alesina, A., Ardagna, S., Perotti, R. and Schiantarelli, F. (2002) Fiscal policy, profits, and investment. The American Economic Review, 92(3), pp. 571-589.

Allingham, M. G. and Sandmo, A. (1972) Income tax evasion: a theoretical analysis. Journal of Public Economics, 1(3), pp. 323-338.

Alm, J., Martinez-Vazques, J. and Schneider, F. (2006) Sizing the problem of the hard to tax, in: J. Alm, J. Martinez-Vazquez and M. Rider (eds) The Challenges of Tax Reform in a Global Economy (New York: Springer), pp. 3-10.

Anderson, J.E. and van Wincoop, E. (2003) Gravity with gravitas: a solution to the border puzzle. American Economic Review, 93(1), pp. 170-192.

Baltagi, B.H. (2005) Econometric Analysis of Panel Data (Chichester: John Wiley and Sons, Ltd.).

Baunsgaard, T. and Keen, M. (2005) Tax revenue and (or?) trade liberalization. IMF Working Paper WP/ 05/112 (Washington, DC).

Cukierman, A., Edwards, S. and Tabellini, G. (1992) Seigniorage and political instability. American Economic Review, 82(3), pp. 537-555.

Ebrill, L., Keen, M., Bodin, J.-P. and Summers, V. (2002) The allure of the value-added tax. Finance and Development, 39(2), pp. 44-47.

Edwards, S. (2007) Capital controls, sudden stops and current account reversals, in: S. Edwards (ed.) Capital Controls and Capital Flows in Emerging Economies: Policies, Practices and Consequences (Chicago: University of Chicago Press), pp. 73-120.

Emran, S.M. and Stiglitz, J.E. (2005) On selective indirect tax reform in developing countries. Journal of Public Economics, 89(4), pp. 599-623.

Engel, E.M.R.A., Galetovic, A. and Raddatz, C.E. (2001) A note on enforcement spending and VAT revenues. Review of Economics and Statistics, 83(2), pp. 384-387.

Financial Times (2006) Evasion and exemptions erode VAT's own value added. Financial Times, 19 June.

Financial Times (2007) Business is blind to the risks of a shared tax system. Financial Times, 15 May.

Fisman, R. and Wei, S-J. (2004) Tax rates and tax evasion: evidence from 'missing imports' in China. Journal of Political Economy, 112(2), pp. 471-500.

Frankel, J.A. and Romer, D. (1999) Does trade cause growth? American Economic Review, 89(3), pp. 379399.

Frankel, J. and Rose, A. (2002) An estimate of the effect of common currencies on trade and income. Quarterly Journal of Economics, 117(2), pp. 437-466.

Giovannini, A. and De-Melo, M. (1993) Government revenue from financial repression. American Economic Review, 83(4), pp. 953-963.

Gordon, R.H. and Li, W. (2007) Puzzling tax structures in developing countries: a comparison of two alternative explanations, in: T. Ito and A.K. Rose (eds.) Fiscal Policy and Management in East Asia, National Bureau of Economic Research - East Asia Seminar on Economics (Chicago: University of Chicago Press), pp. 9-35.

Greene, W.H. (2002) Econometric Analysis (New Jersey: Prentice Hall).

Hall, R.E. and Jones, C.I. (1999) Why do some countries produce much more output per worker than others? Quarterly Journal of Economics, 114(1), pp. 83-116.

Helpman, E., Melitz, M. and Rubinstein, Y. (2007) Estimating Trade Flows: Trading Partners and Trading Volume. Quarterly Journal of Economics, 123(2), pp. 441-487.

Nam, C.W., Gebauer, A. and Parsche, R. (2003) Is the completion of the EU single market hindered by VAT evasion? CESifo Working Paper Series No. 974.

Persson, T. and Tabellini, G. (2003) The Economic Effects of Constitution (Cambridge, MA: MIT Press). Phelps, E.S. (1973) Inflation in the theory of public finance. Swedish Journal of Economics, 75(1), pp. 67-82. Rodrik, D. (1998) Why do more open economies have bigger governments? Journal of Political Economy, 106(5), pp. 997-1032. 
Ruud, P.A. (2000) An Introduction to Classical Econometric Theory (New York: Oxford University Press). Schneider, F.G. (2004) The size of the shadow economies of 145 countries all over the world: first results over the period 1999 to 2003. IZA Discussion Paper No. 1431.

Slemrod, J. (2004) Are corporate tax rates, or countries, converging? Journal of Public Economics, 88(6), pp. 1169-1186.

Slemrod, J. (2007) Cheating ourselves: the economics of tax evasion. Journal of Economic Perspectives, 21(1), pp. 25-48.

Slemrod, J. and Yitzhaki, S. (2002) Tax avoidance, evasion, and administration, in: A.J. Auerbach and M. Feldstein (eds) Handbook of Public Economics (Amsterdam: Elsevier), pp. 1423-1465.

Talvi, E. and Vegh, C.A. (2005) Tax base variability and procyclical fiscal policy in developing countries. Journal of Development Economics, 78(1), pp. 156-190.

Tanzi, V. and Zee, H. (2000) Tax policy for emerging markets: developing countries. National Tax Journal, 53(2), pp. 299-322.

Vegh, C. (1989) Government spending and inflationary finance: a public finance approach. IMF Staff Papers, 36(4), pp. 657-677.

Zellner, A. (1962) An efficient method of estimating seemingly unrelated regression and tests for aggregation bias. Journal of the American Statistical Association, 57, pp. 348-368.

\section{Data Appendix}

Tax revenues: The effective rate of actual revenue collection as a percentage of GDP. VAT (value added taxes), Income Taxes (corporate and personal taxes), and Tariffs (imports and exports trade taxes) are from Office of Tax Policy Research at University of Michigan; http://www.bus.umich.edu/OTPR/. Following Cukierman et al. (1992), Seigniorage is constructed from changes in high-powered (reserve) money from line $14 \ldots$ ZF $\ldots$ of International Financial Statistics (IFS). By tax effort, Tariffs and Seigniorage are easy to collect taxes, whereas VAT and Income Taxes are hard to collect taxes. All of the taxes are divided by GDP.

Globalisation variables: Trade Openness is constructed from gravity regression methodology, using data from NBER-UN World Trade Flows (http://www.nber. org/data/; values of exports and imports), Frankel and Rose (2002) (distance, common official language, common borders, land-area product), World Development Indicators (WDI; population of trading partners, real GDP). Financial Openness is imputed Quinn index from Edwards (2007).

Control variables: Institutional Quality is the composite index of good governance from International Country Risk Guide (http://www.prsgroup.com/). Political Durability is the number of years in power of incumbent government, from Political IV Project (http://www.systemicpeace.org/polity/polity4.htm). Urbanisation and Agricultural Share are from WDI. Government expenditure is from IFS. Weighted tariff rates are derived from reports of the World Bank-Operations Evaluation Department. 